\title{
The Interconnection of Global and Regional Security Systems: the Case of the United Nations, the Collective Security Treaty Organization and the Shanghai Cooperation Organisation ${ }^{1}$
}

\author{
S. Bokeriya
}

Svetlana Bokeriya - PhD, Associate Professor, Department of Theory and History of International Relations, Peoples' Friendship University of Russia; 10 Miklukho-Maklaya Str., Moscow, 117198, Russian Federation; E-mail: bokeria_sa@pfur.ru

\begin{abstract}
This article studies the interconnection of global and regional security systems using the example of the interaction of the United Nations (UN) with the Collective Security Treaty Organization (CSTO) and the Shanghai Cooperation Organisation (SCO). According to the author, their activity is underestimated. These organizations appeared in the wake of the emergence of a pool of regional associations of countries that have become involved in security and peacekeeping activities.

Both associations have a similar composition of members, were established after the collapse of the USSR, are observers in the UN, are engaged in security as one of their key activities, and have similar functions. The CSTO and the SCO prevented new conflicts from breaking out in the post-Soviet space by acting as stabilizing forces within the borders of their regions and the participating states.

This study's relevance is underscored first, by the special role that regional organizations play in building and operating a global security system; second, by the lack of existing research focused on the interaction of the UN with the CSTO and the SCO; and third, by the need to improve the collective mechanisms for responding to new security threats which become intertwined with existing challenges.

The theory of military-political alliances provides the analytical basis of this research. The article uses quantitative and qualitative methods, including analysis of United Nations documents. The interconnection between the UN, SCO and CSTO is analyzed by counting the number of times the keywords "CSTO" and "SCO" appear in UN documents and defining the context of their use over a period of 15 (from 2002 to 2017) and 16 years (from 2001 to 2017) respectively. An extensive database of UN documents was available from the United Nations Bibliographic Information System (UNBISNET). Based on this analysis, an assessment is made of the contribution and interest of the Russian Federation as a leading player in international relations in the process of strengthening the interconnection of global and regional security systems.
\end{abstract}

Key words: UN; regional organizations; regionalization; CSTO; SCO; security; peacekeeping; military alliance

For citation: Bokeriya S. (2019) The Interconnection of Global and Regional Security Systems: the Case of the United Nations, the Collective Security Treaty Organization and the Shanghai Cooperation Organisation. International Organisations Research Journal, vol. 14, no 1, pp. 21-38 (in English). DOI: 10.17323/1996-7845-2019-01-02

${ }^{1}$ The editorial board received the article in January 2018. 


\section{Introduction}

In the context of the globalized development pathway of contemporary international relations characterized by processes that fragment and blur borders outward from the centre, particular importance is attached to the tendency toward political and economic regionalization. Efforts to conceptualize the regional level of intergovernmental cooperation were heavily debated in the 1990s [Voskresenskij, 2012, p. 33]. Researchers insisted on separating the regional level of intergovernmental cooperation into an independent branch for analysis due to the obvious influence of regional actors over the global development of international relations. This influence varied from supporting and strengthening to dismantling and starting certain dramatic global transformational processes. Furthermore, regional organizations play a leading role in arranging regional systems of cooperation between countries and in the nature of the system of international governance and power, exerting influence on the global order.

This article tests the hypothesis that interconnections between global and regional security systems have intensified using the case of cooperation between the United Nations (UN) and two regional organizations - the Collective Security Treaty Organization (CSTO) and the Shanghai Cooperation Organisation (SCO). The primary goals of this research are to examine the role of the CSTO (between 2002 and 2017) and the SCO (between 2001 and 2017) in UN documents based on analysis of their citations over a period of 15 and 16 years, respectively; to explain the mechanisms of interconnection between the UN and regional organizations such as the CSTO and the SCO; and to analyze Russia's point of view with regard to the CSTO and the SCO.

Despite the lack of research on the interaction between the UN and the CSTO and the SCO, there are academic papers, monographs and articles which investigate certain aspects of regional organizations like the CSTO and the SCO. Based on analysis of Russian and international academic resources focused on the activity of the CSTO and the SCO, these can be classified into two groups.

The first group of researchers concentrates on the analysis of certain problematic aspects of the CSTO's activity in terms of its strategy, goals, the unity of the organization and the members' viewpoints. See for example A.I. Nikitin, Ju.A. Nikitina and I.Ju. Jurgens [2011], and E.V. Klevakina [2013]. The second group of researchers focuses on the role of the SCO in Central Asia and the issues associated therewith. See for example E.V. Koldunova, N. Das Kundu [2014], S.G. Luzjanin [2013], A.V. Lukin [2011] and Sin Guanchjen [2002].

The primary trend of research focused on regional organizations with regard to security enforcement is either to analyze one or more organizations located in the same region, thereby ignoring the global context, or to concentrate on international policy or economics without being bound to any particular regional process [Lukin, 2011]. In this context, special mention should be made of the theory of military alliances which foregrounds interconnections between regional and global security systems, as well as processes of multilateral cooperation and power balancing between states. 
According to American professor J. Liska, it is impossible to discuss international relations without analysis of military alliances [Liska, 1968, p. 3]. By "alliance" Liska means a nominal union of more than one state formed in order to confront any threat coming from a third and more powerful state. The formation of military alliances is triggered by conflicts and is informed by balance of power theory which cautions against allowing the military buildup and empowerment of any state within the international system which may compromise sovereignty and security of other political actors.

O. Holsti, T. Hopmann and J. Sullivan point out three characteristics of alliances: first, there is a formal treaty, whether open or secret; second, the treaty must be related to national security problems; and third, partners must be states. According to them, "an alliance is a formal agreement between two or more nations to collaborate on national security issues" [Holsti, Hopmann, Sullivan, 1973, p. 4].

Reinterpreting the concept of power balance, Stephen Walt, an American political expert, developed the "balance of threat" concept based on the argument that, in determining their foreign policies, states follow the dynamic pattern of the regional power balance rather than the global one. An alliance is seen by Walt as "a formal or informal relationship of security cooperation between two or more sovereign states" [Walt, 1987, p. 12].

A characteristic feature of the CSTO and the SCO is that they operate in several regions. However, similar activity areas and fields of interests establish a solid foundation for interaction with organizations on a global scale, and particularly with the UN.

The charter of the CSTO states that it is "the international regional Collective Security Treaty Organization" [CSTO, 2002]. Currently, the organization is comprised of six states: Russia, Belarus, Armenia, Kazakhstan, Kyrgyzstan and Tajikistan. The charter emphasizes the creation of a regional collective security system as the principal goal of the institution.

According to V. Nikishin, head of the CSTO Information Programs Department, "what's unique about the CSTO is that it has the aggregate set of tools for security purposes of the member countries and the union at large: from political ammunition to its own military capability" [RIA Novosti, 2016]. A booklet dedicated to the 20th anniversary of the CSTO states that it "became a unique tool able to claim responsibility for the stability and safety of nations in times of peace and in case of any potential aggression as well" [CSTO, 2012]. The CSTO created mechanisms meant to stand against contemporary challenges and security threats, and on a periodic basis the organization undertakes operations such as "Channel," "Illegal Immigrant" and "Proxy," aimed at preventing drug traffic, illegal migration and criminal use of cyberspace, respectively. For security purposes the CSTO has signed and ratified 48 international agreements and over 227 resolutions of the Collective Security Council with regard to various aspects of the organization's activity. In 2016, the CSTO Collective Security Council session approved a list of terrorist organizations which has no equal in any other international organization. In the same year the CSTO paid attention to measures aimed at enhancing the efficiency of counterterrorism efforts as part of the organization's ac- 
tivity. The CSTO's collective dynamic response forces were supplemented by special operations forces drawn from members' law enforcement bodies and security structures [Hachaturov, 2017].

The SCO's official website describes the organization as "a permanent regional international organization established in 2001 by the leaders of Kazakhstan, China, Kirghizia, Russia, Tajikistan, and Uzbekistan" [SCO, c. a.].

According to N. Nazarbaev, the peculiarity of the SCO is "its ability to solve international issues via political and diplomatic means." This organization is distinct from other institutions due to the flexibility of the tools it uses - soft power and diplomatic methods - to achieve its goals. Furthermore, Ban Ki-moon, secretary-general of the United Nations, emphasized that the SCO was the leading regional international organization of the Eurasian continent [Nazarbaev, 2011].

According to T. Shaimergenov, the unique character of the SCO is that it serves as "a single dialogue field" which harmonizes claims of other parties and synchronizes regional processes [Akhmetov, 2012, p. 13]. The SCO contributes to the peaceful recovery in Afghanistan and has undertaken groundwork for an anti-drug security belt along Afghanistan's borders. Since 2002, the SCO has maintained the Regional AntiTerrorist Structure aimed at managing operations associated with searching terrorist training camps and uncovering their financial arrangements. According to the authors of a Valdai Discussions Club report, the SCO unites Central Asia into a single region and more broadly acts "as an element of Eurasian regionalism." It is against this background that the SCO, while having an institutional structure, does not prejudice the national interests of its members [Koldunova, Das Kundu, 2014].

Since 2004, the CSTO and the SCO have been observers of the UN General Assembly (UN GA); relevant resolutions were approved by consensus. A joint declaration between the UN and the CSTO was signed in Moscow on 18 March 2010 which specifies the format for cooperation between the two organizations and refers to peacemaking efforts in particular. The CSTO expressed its willingness to provide peacekeeping forces in order to participate in joint operations managed by the UN. Two years later, the CSTO and the UN Department of Peacekeeping Operations signed a memorandum of understanding related to conflict prevention and peacekeeping activities. The memorandum called for strengthening mechanisms for better cooperation among the peacemaking groups of CSTO members.

On a permanent basis, CSTO members provide advisory services regarding the agenda of UN GA sessions. There is effective teamwork between international organizations and committees, especially with respect to the Counterterrorism Committee of the UN Security Council, the UN Office for Drugs and Crime, the European Union and the Organization for Security and Co-operation in Europe.

A memorandum of understanding between the CSTO and the executive directorate of the Counterterrorism Committee of the UN Security Council was signed on 23 September 2016 in addition to the approved cooperation agreements between the CSTO and the UN. 
When UN observer status was awarded in 2009 the UN GA adopted Resolution A/RES/64/183 (agenda item 124) "Cooperation between the UN and SCO" which foregrounded the issues associated with strengthening bilateral dialogue, and the cooperation and coordination of joint efforts. A year later, in Tashkent, the secretariesgeneral of the $\mathrm{UN}$ and the SCO signed a joint declaration on cooperation with regard to information exchange activities. At the request of the UN, the SCO secretariat together with members and the SCO Regional Anti-Terrorist Structure regularly convey information associated with the implementation of UN GA resolutions.

In 2016, on a panel session regarding UN-SCO cooperation, R. Alimov, the SCO secretary-general stated that the SCO, being a multipurpose institution, has 28 mechanisms of practical cooperation which together form a solid foundation for cooperation with the UN in regard to economics and humanitarian assistance, as well as on security activity [SCO, 2016].

The key regulator of UN relations with regional organizations is Chapter VIII of the UN Charter which makes official reference to UN Security Force (UNSF) control and conformity. The charter applies to any and all institutional formations involved with peacemaking and security. The core requirement is to act in accordance with UN principles and to apply enforcement measures subject only to the relevant UNSF sanctions.

Notwithstanding the positive dynamics of cooperation between the UN and the CSTO and SCO, it is worth noting that their development paths face two challenges: first, the lack of any practice related to the management sphere boundary delimitation in terms of security enforcement issues, and second, the fact that the mechanism for taking action is primarily based on cooperation between the organizations' secretariats, which significantly weakens implementation of any collective measures.

\section{Research Methodology}

To investigate the interconnection of global and regional systems of security, UN documents containing references to the CSTO and the SCO were examined for the period of 2002-2017 and 2001-2017, respectively. In the case of the SCO, the starting date coincides with the organization's establishment. The research data set included documents from the UN GA (reports, resolutions, letters and the verbal notes of UN permanent representatives), the UNSF (communique, letters) and UN agencies; the review made note of the context (subject, part of a document) in which the references to the CSTO and the SCO were made. Based on this analysis, the key subjects in regard to which the $\mathrm{UN}$ addressed the regional organizations of the CSTO and the SCO were be identified.

Electronic versions of UN GA and UNSF documents published between 2001 and 2017 were compiled. During this period the UN approved 78 documents containing references to the CSTO and 75 documents with references to the SCO. Analysis of these 154 documents shows that in 15 years there were 407 references to the CSTO, whereas there were 755 references to the SCO in 16 years, which is almost twice the 
references to the CSTO. Quantitative and qualitative analyses of references of the UN to the CSTO and the SCO activity was carried out.

\section{Graph Data Analysis}

Figure 1 shows the number of UN documents containing references to the CSTO for the period 2002-2017 and reflects the uneven pattern of interest on the part of the UN towards the CSTO. In 2010 and 2012 references to the CSTO peaked in UN documents, while the lowest number of references occurred in 2002 and 2017. The escalation is related to the expansion of cooperation between the UN and the CSTO, as well as to the 2010 Kirghiz revolution. The decrease in 2002 is associated with the process of formation of the CSTO in the same year (the CSTO charter was adopted in 2002) whereas in 2017 the CSTO predominantly concentrated on military exercises in order to train its operating forces for UN peace support missions. The year 2002 was a bridge year in the history of the CSTO across the two stages of development of the organization, 1992-2002 and 2002-2009; the first period is characterized by lower efficiency and aggravations between members; the second, by increased activity against the background of unresolved issues carried over from the first period [Akulik, Bobkob, Levjash, 2011, p. 289].

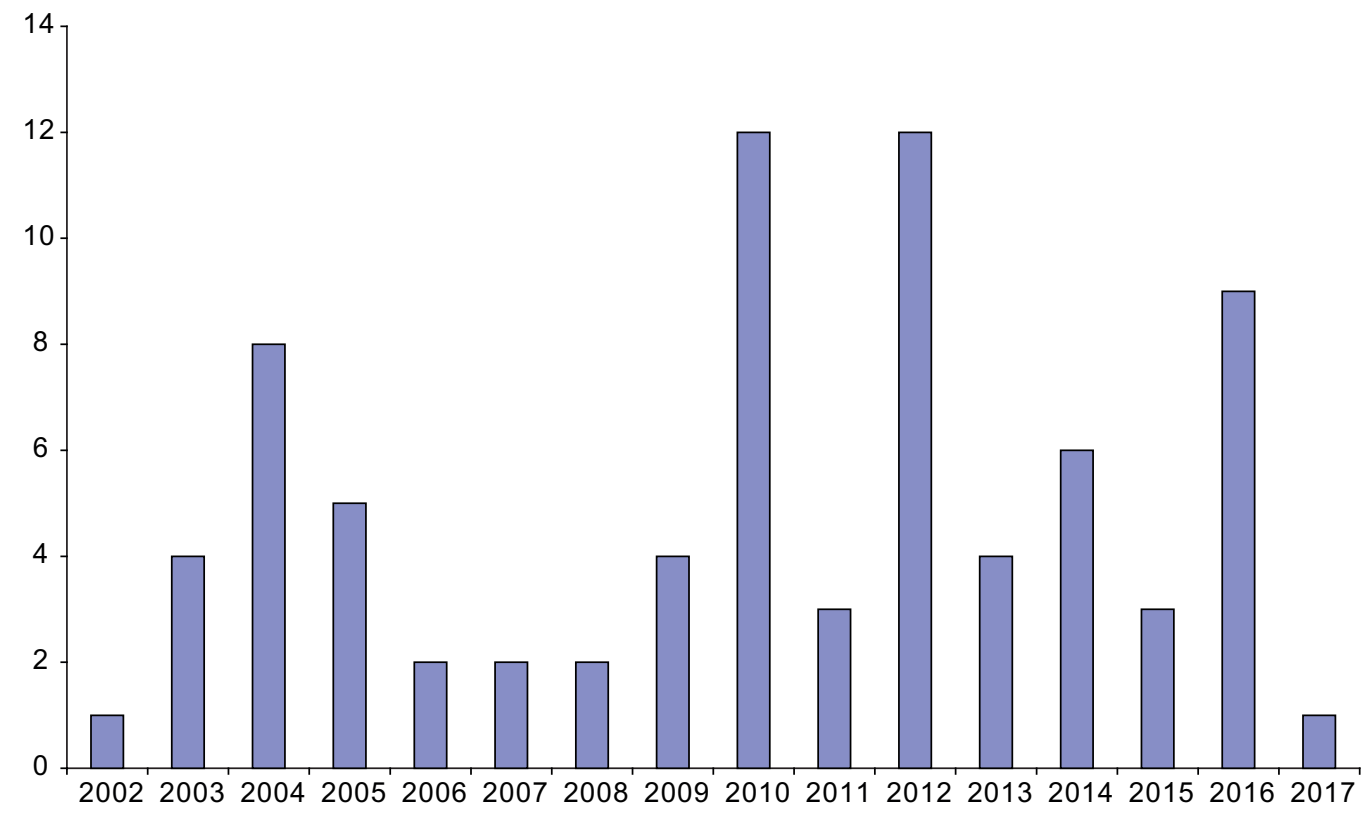

Fig. 1. Number of UN Documents with References to the CSTO (2002-2017)

Source: compiled by the author based on analysis of documents published on UNBISNET. 
In the history of cooperation between the UN and the CSTO, 2012 is marked by the adoption of UN GA Resolution No. 67/6, "Cooperation between the UN and the CSTO," which formed the legal basis for pragmatic teamwork between the UN and the CSTO.

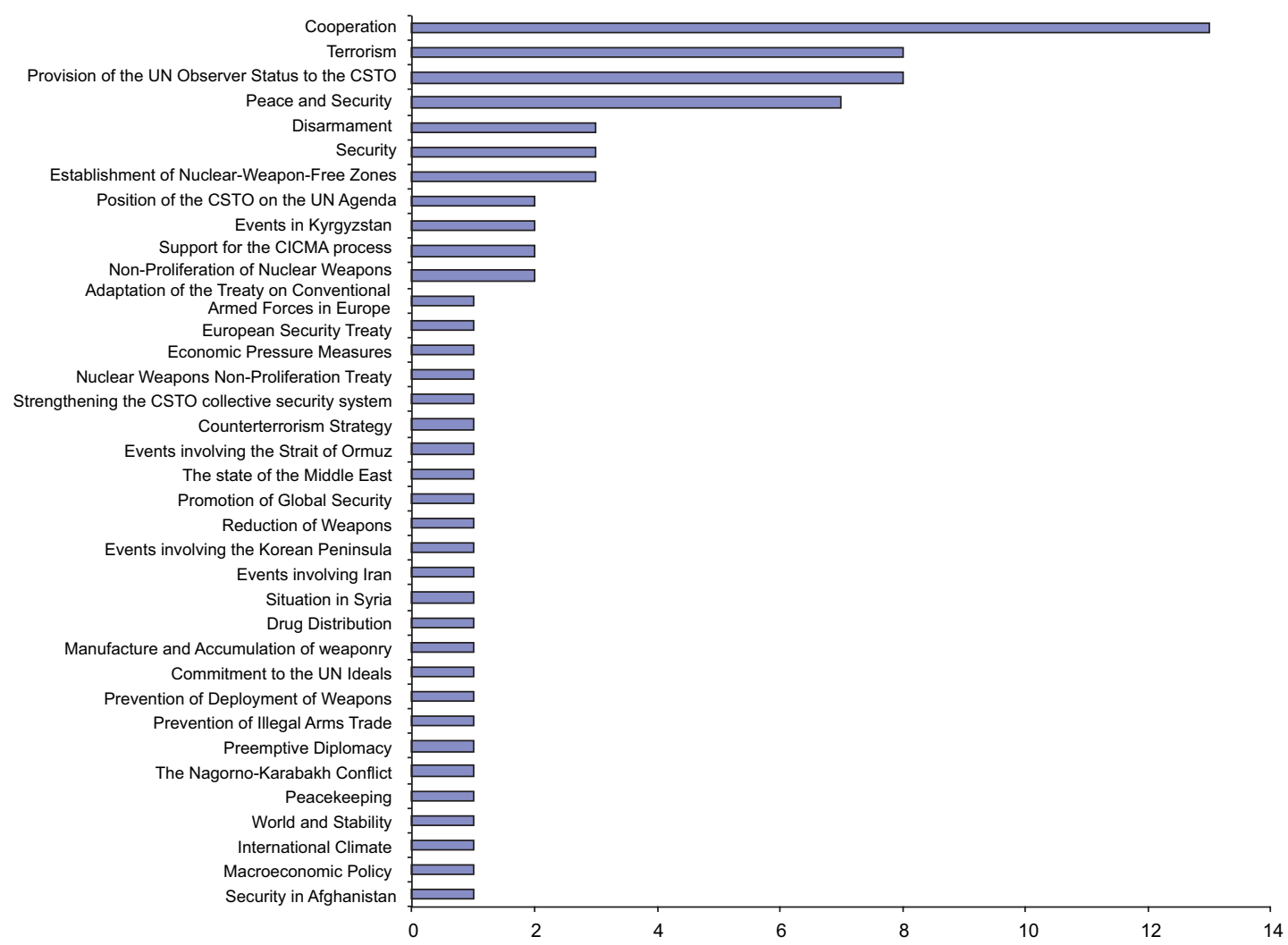

Fig. 2. Distribution of UN Documents Referring to the CSTO According to Subject Matter (2002-2017)

Source: compiled by the author based on analysis of documents published on UNBISNET.

Figure 2 shows the distribution of UN documents referring to the CSTO according to subject matter over the 15-year period under review. Between 2002 and 2017, the CSTO was referenced in the context of 36 subjects: from security in Afghanistan to UN cooperation. It is apparent that cooperation is the leading context for references to the CSTO. References in the context of terrorism and provision of GA observer status to the CSTO appear in the same number of documents in 2004. The year 2014 was characterized by an escalation of two problematic situations - the Ukraine conflict and withdrawal of the International Security Assistance Force from Afghanistan.

Next follows subject matter related to maintaining peace and security while references to the CSTO in the context of other subject matter appear less frequently. 
Table 1. Frequency and Number of CSTO References in UN Documents According to Subject Matter (2002-2017)

\begin{tabular}{|c|c|c|c|c|c|c|c|c|c|c|c|c|c|c|c|c|c|}
\hline Subject Matter & 气ิ & ֻัণ & ఫ্ণ & 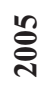 & ஓ્̀ & હે & 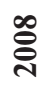 & ڤ્নે & 을 & $\overline{\overline{7}}$ & 글 & 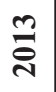 & ت্ & 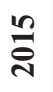 & 룩 & בั่ & $\begin{array}{l}\text { Sum } \\
\text { Total }\end{array}$ \\
\hline Peace and Security & & & & 3 & & & & & & & 17 & 22 & 31 & & 6 & & 79 \\
\hline Cooperation & & & & & & & & 14 & 36 & 10 & 8 & & 4 & & 4 & & 76 \\
\hline $\begin{array}{l}\text { Provision of the GA } \\
\text { Observer Status } \\
\text { to the CSTO }\end{array}$ & & & 37 & & & & & & & & & & & & & & 37 \\
\hline Terrorism & & 7 & & & & & & & & & 2 & 6 & & 3 & 10 & 3 & 31 \\
\hline Peacekeeping & & & & & & & & 19 & & & & & & & & & 19 \\
\hline Security & 7 & 4 & & & & & & & & & & & & & 5 & & 16 \\
\hline Disarmament & & & & 6 & & 6 & 2 & & & & & & & & & & 14 \\
\hline $\begin{array}{l}\text { Support for the } \\
\text { CICMA Process }\end{array}$ & & & & & & & & & & & 11 & & & & & & 11 \\
\hline $\begin{array}{l}\text { Prevention of Illegal } \\
\text { Arms Trade }\end{array}$ & & & & & 8 & & & & & & & & & & & & 8 \\
\hline $\begin{array}{l}\text { Non-Proliferation } \\
\text { of Nuclear Weapons }\end{array}$ & & & & 3 & & & & & 3 & & & & & & & & 6 \\
\hline $\begin{array}{l}\text { Preemptive } \\
\text { Diplomacy }\end{array}$ & & & & & & & & & & & & & 6 & & & & 6 \\
\hline Situation in Syria & & & & & & & & & & & & 6 & & & & & 6 \\
\hline $\begin{array}{l}\text { Events in } \\
\text { Kyrgyzstan }\end{array}$ & & & & & & & & & 6 & & & & & & & & 6 \\
\hline $\begin{array}{l}\text { Establishment of } \\
\text { Nuclear-Weapon- } \\
\text { Free Zones }\end{array}$ & & & & & 5 & & & & & & 3 & & 3 & & & & 11 \\
\hline $\begin{array}{l}\text { Commitment to the } \\
\text { UN Ideals }\end{array}$ & & & & 4 & & & & & & & & & & & & & 4 \\
\hline $\begin{array}{l}\text { Events Involving } \\
\text { Iran }\end{array}$ & & & & & & & & & & & 4 & & & & & & 4 \\
\hline $\begin{array}{l}\text { Reduction of } \\
\text { Weapons }\end{array}$ & & & & & & & & & 4 & & & & & & & & 4 \\
\hline Peace and Stability & & & & & & & & & & & 3 & & & & & & 3 \\
\hline $\begin{array}{l}\text { Security in } \\
\text { Afghanistan }\end{array}$ & & 2 & & & & & & & & & & & & & & & 2 \\
\hline $\begin{array}{l}\text { International } \\
\text { Climate }\end{array}$ & & & & & & & & 2 & & & & & & & & & 2 \\
\hline $\begin{array}{l}\text { Prevention of } \\
\text { Deployment of } \\
\text { Weapons }\end{array}$ & & & & & & & & & & & & & & 2 & & & 2 \\
\hline $\begin{array}{l}\text { Manufacture and } \\
\text { Accumulation of } \\
\text { Weaponry }\end{array}$ & & & & & & & & & & 2 & & & & & & & 2 \\
\hline Drug Distribution & & & & & & & & & & 2 & & & & & & & 2 \\
\hline $\begin{array}{l}\text { Events Involving the } \\
\text { Korean Peninsula }\end{array}$ & & 2 & & & & & & & & & & & & & & & 2 \\
\hline
\end{tabular}




\begin{tabular}{|c|c|c|c|c|c|c|c|c|c|c|c|c|c|c|c|c|c|}
\hline Subject Matter & ฮั่ & ฮิ & ஓ্ণ & 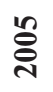 & ๕ั่ & ฮิ & 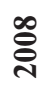 & ڤ્নે & 윰 & $\overline{\overline{7}}$ & ำ & $\stackrel{\text { m }}{\stackrel{n}{\pi}}$ & ت্ণ & 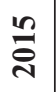 & 룰 & 글 & $\begin{array}{l}\text { Sum } \\
\text { Total }\end{array}$ \\
\hline $\begin{array}{l}\text { Promotion of } \\
\text { Global Security }\end{array}$ & & & & & & & 2 & & & & & & & & & & 2 \\
\hline $\begin{array}{l}\text { The State of the } \\
\text { Middle East }\end{array}$ & & & & & & & & & & & & & 2 & & & & 2 \\
\hline $\begin{array}{l}\text { Macroeconomic } \\
\text { Policy }\end{array}$ & & & & & & & & & & & & & & & 1 & & 1 \\
\hline $\begin{array}{l}\text { The Nagorno- } \\
\text { Karabakh Conflict }\end{array}$ & & & & & & 1 & & & & & & & & & & & 1 \\
\hline $\begin{array}{l}\text { Events Involving the } \\
\text { Strait of Ormuz }\end{array}$ & & & & & & & & & & & 4 & & & & & & 4 \\
\hline $\begin{array}{l}\text { Counterterrorism } \\
\text { Strategy }\end{array}$ & & & & & & & & & & & & & & & 6 & & 6 \\
\hline $\begin{array}{l}\text { Position of the } \\
\text { CSTO on the UN } \\
\text { Agenda }\end{array}$ & & & & & & & & & & & 8 & & & 11 & & & 19 \\
\hline $\begin{array}{l}\text { Strengthening the } \\
\text { CSTO Collective } \\
\text { Security System }\end{array}$ & & & & & & & & & & & & 8 & & & & & 8 \\
\hline $\begin{array}{l}\text { Nuclear Weapons } \\
\text { Non-Proliferation } \\
\text { Treaty }\end{array}$ & & & & & & & & & & & 3 & & & & & & 3 \\
\hline $\begin{array}{l}\text { Economic Pressure } \\
\text { Measures }\end{array}$ & & & & & & & & & & & 3 & & & & & & 3 \\
\hline $\begin{array}{l}\text { European Security } \\
\text { Treaty }\end{array}$ & & & & & & & & 2 & & & & & & & & & 2 \\
\hline $\begin{array}{l}\text { Adaptation of } \\
\text { the Treaty on } \\
\text { Conventional } \\
\text { Armed Forces in } \\
\text { Europe }\end{array}$ & & & & 3 & & & & & & & & & & & & & 3 \\
\hline
\end{tabular}

Source: compiled by the author based on analysis of documents published on UNBISNET.

Table 1 shows subject themes by year and the number of the CSTO references found in UN documents. Table 1 data have been sorted in descending order for a period of 15 years, from 2002 to 2017. Among the most referenced themes are peace and security, cooperation and provision of GA observer status to the CSTO, followed by terrorism and peacekeeping.

UN GA Resolution No. $65 / 122$ (2010) on cooperation between the UN and the CSTO underlined the importance of strengthening bilateral dialogue, cooperation and coordination, and approved the mechanism of regular counselling with the UN and CSTO secretaries-general by virtue of interagency fora and formats, including annual counselling with the UN secretary-general and heads of regional organizations [UN, 2010]. Furthermore, UN GA resolutions of cooperation between the UN and the CSTO are adopted every two years starting from 2010: 2014 (69/12), and 2016 (71/12). 
Issues related to cooperation between the UN and the CSTO were included on the agenda of the 67th UN GA session. Counselling with the secretariats of the UN and the CSTO with regard to building relations between these organizations, particularly in peacemaking activity, took place in May 2011 in New York.

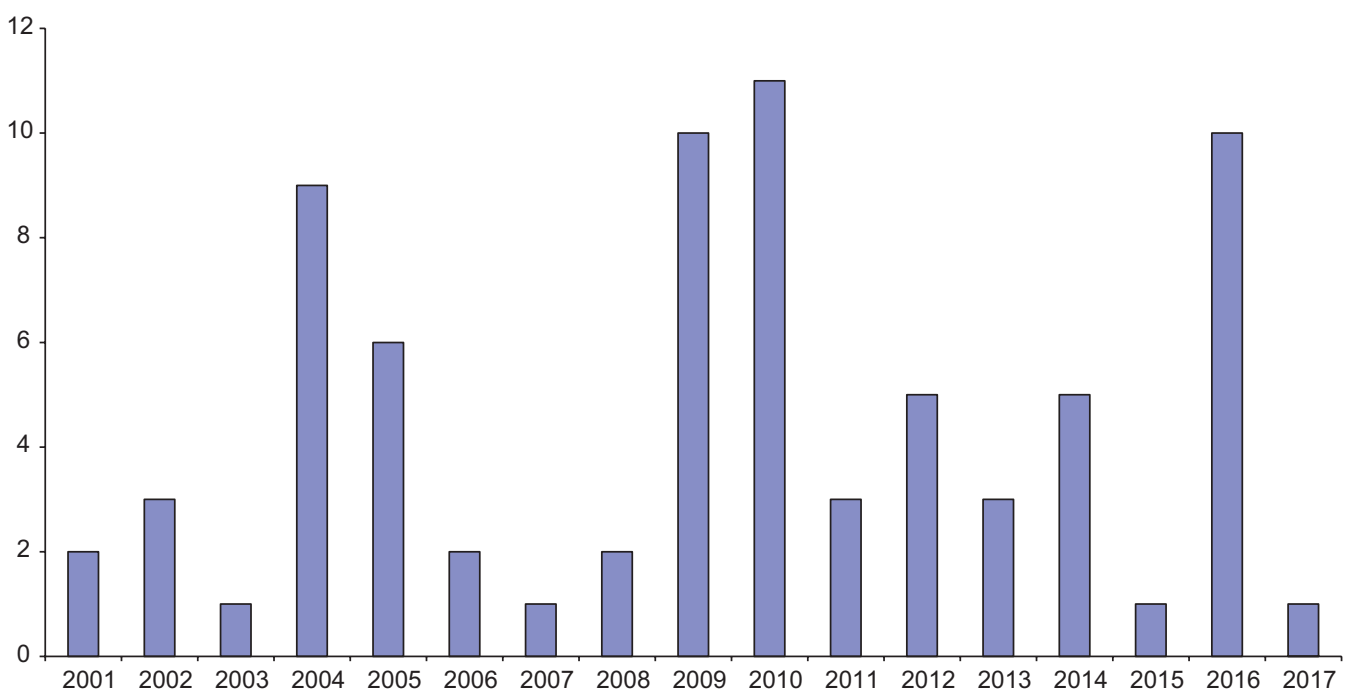

Fig. 3. The Number of UN Documents with SCO References (2001-2017)

Source: complied by the author based on analysis of documents published on UNBISNET.

Figure 3 shows that the highest number of references to the SCO in UN documents occured in 2010, 2009 and 2016. When comparing Fig. 1 and Fig. 3, peak values with regard to both the CSTO and the SCO occurred in 2010. In the case of the SCO, themes include security enforcement and counterterrorism efforts, while the CSTO was mentioned due to the conflict in Kirgizia. In 2009 SCO references in UN documents were related to themes such as security, cooperation with the UN and counterterrorism activity. In 2016 the SCO was most frequently mentioned in UN documents in relation to themes such as peace and security and counterterrorism efforts. In the same year, the UN GA approved Resolution No. 71/14, "Cooperation between the UN and the SCO," by acclamation; this resolution set out basic mechanisms of cooperation with the SCO. Pragmatic cooperation formats involved communications, joint expert valuation and common arrangements.

Figure 4 details the distribution of $\mathrm{UN}$ documents according to the subject matter associated with references to the SCO for the 16-year period under review. There are 15 subject matters, which is 21 fewer than in the case of the CSTO. This leads to the conclusion that cooperation with the CSTO occurs on a greater number of issues with the leading subjects being terrorism, security and events in Afghanistan. These are followed by peace and security, in the same way as for the CSTO in Fig. 2. Provision of GA observer status to the SCO falls even lower. 


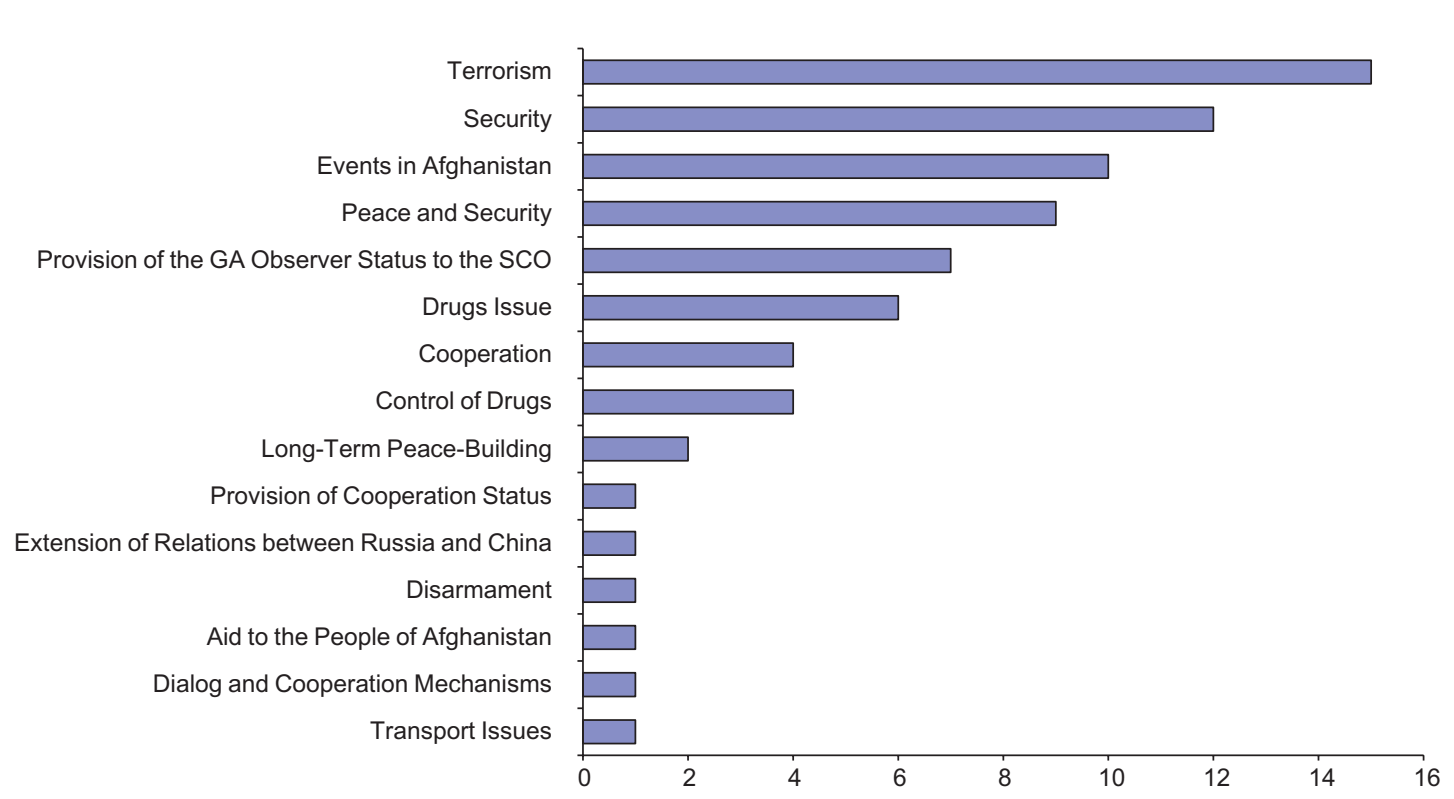

Fig. 4. References to the SCO in UN Documents According to Subject Matter (2001-2017)

Source: compiled by the author based on analysis of documents published on UNBISNET

Table 2. Frequency and Number of References to the SCO in UN Documents According to Subject Matter (2001-2017)

\begin{tabular}{|c|c|c|c|c|c|c|c|c|c|c|c|c|c|c|c|c|c|c|}
\hline Subject Matter & ठ্ণิ & ฮิ & ஜิ̊ి & 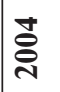 & ஜิ & ‡ั & ฮิ & 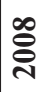 & ठ্ণิ & 윰 & 콕 & 골 & 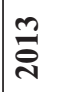 & ت্ & 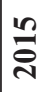 & 율 & 곡 & $\begin{array}{l}\text { Sum } \\
\text { Total }\end{array}$ \\
\hline $\begin{array}{l}\text { Peace and } \\
\text { Security }\end{array}$ & & & & & & & & & & & & & & 66 & & 141 & & 207 \\
\hline Terrorism & 16 & 9 & & & 7 & & & & 13 & 9 & & & 51 & 8 & 3 & 21 & 11 & 148 \\
\hline Security & & & & & & & & 4 & 17 & 32 & & 47 & 6 & & & & & 106 \\
\hline $\begin{array}{l}\text { Control of } \\
\text { Drugs }\end{array}$ & 60 & & & 7 & & 21 & & & 2 & & & & & & & & & 90 \\
\hline $\begin{array}{l}\text { Provision of the } \\
\text { GA Observer } \\
\text { Status to the } \\
\text { SCO }\end{array}$ & & & & 50 & 3 & & & & & & & & & & & & & 53 \\
\hline Drugs Issue & & & & & & & & & 8 & 1 & 16 & 9 & & & & 3 & & 37 \\
\hline $\begin{array}{l}\text { Events in } \\
\text { Afghanistan }\end{array}$ & & 9 & 5 & & 11 & & 4 & 1 & 3 & 2 & & & & & & & & 35 \\
\hline Cooperation & & & & & & & & & 32 & 2 & & & & & & & & 34 \\
\hline Transport Issues & & & & 16 & & & & & & & & & & & & & & 16 \\
\hline Disarmament & & & & & & 9 & & & & & & & & & & & & 9 \\
\hline $\begin{array}{l}\text { Dialogue and } \\
\text { Cooperation } \\
\text { Mechanism }\end{array}$ & & & & & 5 & & & & & & & & & & & & & 5 \\
\hline
\end{tabular}




\begin{tabular}{|c|c|c|c|c|c|c|c|c|c|c|c|c|c|c|c|c|c|c|}
\hline Subject Matter & ठั. & ণิ & ஜิ & ఫ্ & ๕ి & ஓి & ڤ్ & ஓ્ণ & ஓ્ন & 육 & ন্ন & 굴 & $\stackrel{m}{\stackrel{n}{2}}$ & ন্ & $\frac{n}{2}$ & 串 & 호 & $\begin{array}{l}\text { Sum } \\
\text { Total }\end{array}$ \\
\hline $\begin{array}{l}\text { Aid to the } \\
\text { People of } \\
\text { Afghanistan }\end{array}$ & & & & & 4 & & & & & & & & & & & & & 4 \\
\hline $\begin{array}{l}\text { Long-Term } \\
\text { Peace-Building }\end{array}$ & & & & & & & & & & & 2 & 2 & & & & & & 4 \\
\hline $\begin{array}{l}\text { Extension } \\
\text { of Relations } \\
\text { between Russia } \\
\text { and China }\end{array}$ & & & & & & & & & & 4 & & & & & & & & 4 \\
\hline $\begin{array}{l}\text { Provision of } \\
\text { Cooperation } \\
\text { Status }\end{array}$ & & & & 3 & & & & & & & & & & & & & & 3 \\
\hline
\end{tabular}

Source: compiled by the author based on analysis of documents published on UNBISNET.

Table 2 provides data regarding the themes and number of SCO references in UN documents each year. Table 2 data have been provided in descending order for a period of 16 years, from 2001 to 2017. Among the most referenced themes are peace and security and terrorism and security, followed by control of drugs and provision of GA observer status to the SCO.

\section{The Stance of the Russian Federation in Terms of the Strategy and Activity of the CSTO and the SCO}

Russia, being guided by the goal of enhancing cooperation with neighbouring countries - former Soviet Union states - is fully engaged in international processes within the Commonwealth of Independent States (CIS), the Customs Union, the Eurasian Economic Community, the Common Free Market Zone, the SCO and the CSTO.

During his speech at the UN meeting in 2016 focused on cooperation of the UN with the CSTO and the SCO, B. I. Churkin, Russia's permanent representative to the UN, noted that cooperation with these organizations is one of the priorities of Russia's foreign policy. However, he emphasized that such cooperation had a substantial potential but "had not been used to the full extent yet" [Permanent Mission of the Russian Federation to the UN, 2016]. Furthermore, the speech touched on the issue of limited awareness of the members of the international community with regard to the activities of the these organizations, which may lead to a corrupted understanding of their role in peacemaking and the stability of the region. In addition, there is the issue of marginalization of these institutions as a result of geopolitical competition among several UNSF members.

Crucial issues in the CSTO region include terrorism, and in particular the spread of ISIS' ideology. Lack of stability in Afghanistan, the related problem of drug trafficking and the spate of criminal activity in the region are also causing concern. The CSTO developed its own tools aimed at combating these threats and risks. Exercises of 
the CSTO Collective Rapid Reaction Force, Cobalt-2016, aimed at combatting terrorism and drug trafficking, took place in May 2016. "Channel," the anti-drug operation, showed good results as well. There is a mutual interest on the part of the UN and the CSTO regarding the development of practical cooperation with regard to peacekeeping, fighting crime and terror. Following proper training, a contingent of peacekeeping forces will participate in UN peace support missions.

Russia assigns high priority to the role of the CSTO regarding security enforcement in the Eurasian region. It has been approved by signing official documents. The 2016 Foreign Policy Concept of the Russian Federation (art. 52) states that the CSTO is "one of the key elements of the current security framework in the post-Soviet space." Hence, it appears that the CSTO is mostly targeted at regional issues rather than at solving global security issues. Russia seeks to facilitate "proper development of the CSTO into a prominent multifunctional international organization capable of overcoming challenges and threats today's world is facing amid the growing pressure from various global and regional factors" [Ministry of Foreign Affairs of Russia, 2016].

The 2015 National Security Strategy of the Russian Federation (art. 90) states that Russia advocates for "the quality development of the CSTO and its conversion into a universal international organization capable of confronting regional challenges and military-political and military-strategic threats and also threats in the information sphere" [Official Internet Portal of Legal Information, 2018].

The above-mentioned documents contain references to the country's stance towards the SCO as well. Art. 79 of the Foreign Policy Concept emphasizes that "Russia attaches importance to further strengthening the SCO's role in regional and global affairs and expanding its membership, and stands for increasing the SCO's political and economic potential, and implementing practical measures within its framework to consolidate mutual trust and partnership in Central Asia, as well as promoting cooperation with the SCO member states, observers and dialogue partners" [Ministry of Foreign Affairs of Russia, 2016].

The SCO's key area of activity is security enforcement within its members' borders. It faces challenges similar to those faced by the CSTO: terrorism, extremism, drug trafficking, cross-border criminality and the state of affairs in Afghanistan. Russia advocates for SCO capacity building, development of the security agencies as part of the UN and an anti-drug strategy. Other activities include the SCO Programme of Cooperation in the Fight against Terrorism, Separatism and Extremism for 2016-2018, the SCO Anti-Extremism Convention and "Peaceful Mission" counterterrorism exercises.

With regard to the SCO, the 2015 National Security Strategy of Russia (art. 92) states that "the Russian Federation attaches importance to building up the political and economic potential of the SCO and to the stimulation within it of practical actions furthering mutual confidence-building and partnership in Central Asia and also to the development of cooperation with the members, observers, and partners of the organization” [Official Internet Portal of Legal Information, 2018]. 
According to the Foreign Policy Concept, first, SCO activity exerts influence on the formation of the global collective leadership system; second, the SCO shall become a composite member of regional partnership organizations within the Asia-Pacific region. Third, the SCO together with the CIS, the UN and the CSTO shall play a crucial role in stabilizing Afghanistan after 2014 [Ministry of Foreign Affairs of Russia, 2016].

According to the point of view of Russian experts, the strategic importance of the SCO involves creating an additional security belt along Russian borders [Bailes et al., 2007, p. 44].

\section{Conclusion}

The UN, despite the difference of resources, capacities and mandates of the organizations, still focuses on strategic cooperation with the CSTO and the SCO, largely due to the fact that it seems hard to cope with the rising and mutually-dependent threats acting alone. The SCO is more frequently referred to in UN documents; however the CSTO dominates in regard to the number of subject matters. The key subject matters of UN-CSTO cooperation over 15 years include cooperation, terrorism and provision of GA observer status to the CSTO; as to UN-SCO cooperation, the key matters are terrorism, security and events in Afghanistan.

Major mechanisms of cooperation between the UN and the CSTO include regular counselling with the UN and CSTO secretaries-general by virtue of joint fora and formats, including annual counselling with the UN secretary-general and heads of regional organizations; practice related to training of special forces units to participate in UN peacemaking missions and mutual cooperation between the UN agencies occurs by executing memoranda with the secretariats. Key cooperation arrangements between the UN and the SCO include communications, joint expert work and activities (meetings, conferences, summits, etc.), and, in the same way as for the CSTO, cooperating with UN specialized structures by executing memoranda with the secretariats which, according to a number of researchers, is insufficient in terms of achieving the optimum effect of cooperation. Further, the CSTO and the SCO take part in UN GA meetings.

Russia is involved in the activities of the CSTO and the SCO and is interested in strengthening and promoting their strategies with due regard to UN goals and principles. However, the CSTO is more of a military and political element in a security enforcement system, while the SCO is a mechanism of regional cooperation with regard to a number of spheres, including the power industry, economics and humanities.

Against the background of the increasing role of regionalism in international relations, the interconnection between global and regional security systems is strengthening as well, which is evidenced by the interaction between the UN and the CSTO and the SCO, despite the differences in intensity, dynamics and mechanisms of cooperation between them. 


\section{References}

Akhmetov Y.B. (2012) Uspehi ShOS i obespechenie regional'noj voenno-politicheskoj bezopasnosti: mezhdisciplinarnyj podhod [SCO and Ensuring Regional Military-Political Security: An Interdisciplinary Approach]. KazNU Bulletin, no 4 (60), pp. 11-16. (In Russian)

Akulik A.K., Bobkov V.A., Levjash I.Ja. (2011) Belarus' v integracionnyh proektah [Belarus in Integration Projects]. Minsk: Belarusian Science. (In Russian)

Bailes A., Dunay P., Guang P., Troitsky M. (2007) Shanghai Cooperation Organization. Stockholm: SIPRI.

Collective Security Treaty Organization (CSTO) (2002) Charter. Available at: http://www.odkb-csto. org/documents/detail.php?ELEMENT_ID=124 (accessed 11 December 2017). (In Russian)

Collective Security Treaty Organization (CSTO) (2012) Collective Security Treaty 20th Anniversary: 1992-2012. Available at: http://www.odkb-csto.org/media/buklet.pdf (accessed 11 December 2017). (In Russian)

Guanchjen S. (2002) Shanhajskaja organizacija sotrudnichestva v bor'be s terrorizmom, jekstremizmom i separatizmom [The SCO in Fighting Terrorism, Extremism and Separatism]. Central'naja Azija i Kavkaz, no 4, pp. 13-21. (In Russian)

Hachaturov Ju. (2017) ODKB - 15 let vmeste vo imja bezopasnogo mira i stabil'nogo razvitija [The CSTO - 15 Years Together in the Name of a Secure Peace and Stable Development]. TASS. Available at: http://tass.ru/opinions/4276931 (accessed 15 December 2017). (In Russian)

Holsti O., Hopmann T., Sullivan J. (1973) Unity and Disintegration in International Alliances: Comparative Studies. New York: John Wiley \& Sons.

Klevakina E.V. (2013) Organizacija Dogovora o kollektivnoj bezopasnosti v kontekste nacional'nyh interesov stran-uchastnic [Collective Security Treaty Organization in the Context of the National Interests of the Member-states]. Vestnik mezhdunarodnyh organizacij, no 2, vol. 8, pp. 111-129. (In Russian)

Koldunova E., Das Kundu N. (2014) Rol' Rossii v ShOS i Central'noj Azii: vyzovy i vozmozhnosti [The Role of Russia in the SCO and Central Asia: Challenges and Opportunities]. Valdai Discussion Club Grantees Report, December. Available at: http://vid-1.rian.ru/ig/valdai/SCO_rus.pdf (accessed 20 December 2017). (In Russian)

Kulik S.A., Nikitin A.I., Nikitina Ju.A., Jurgens I.Ju (ed.). (2011) ODKB: otvetstvennaja bezopasnost' [CSTO: Responsible Security]. Moscow: INSOR.

Liska G. (1968) Nations in Alliance: The Limits of Interdependence. Baltimore: Johns Hopkins Press.

Lukin A.V. (2011) Shanhajskaja organizacija sotrudnichestva i rossijskie interesy v Central'noj Azii i Afganistane [The Shanghai Cooperation Organization Politics in Central Asia and Afghanistan]. Vestnik MGIMO Universiteta, no 5, pp. 37-47. (In Russian)

Luzjanin S.G. (2013) Shanhajskaja organizacija sotrudnichestva 2013-2015: prognozy, scenarii i vozmozhnosti razvitija [Shanghai Cooperation Organization 2013-2015: Forecasts, Scenarios and Development Opportunities]. Institut Dal'nego Vostoka RAN. (In Russian)

Ministry of Foreign Affairs of Russia (2016) Koncepcija vneshnej politiki RF ot 2016 goda [Foreign Policy Concept of Russia, 2016]. Available at: http://www.mid.ru/foreign_policy/news/-/asset_publisher/ cKNonkJE02Bw/content/id/2542248 (accessed 13 December 2017). (In Russian)

Nazarbaev N.A. (2011) Evrazijskij Sojuz: ot idei k istorii budushhego [Eurasian Union: From Idea to History of the Future]. Izvestija. Available at: http://izvestia.ru/news/504908 (accessed 21 December 2017). (In Russian)

Permanent Mission of the Russian Federation to the UN (2016) Speech by Vitaly Churkin, Permanent Representative of the Russian Federation to the UN, at a Meeting of the UN Security Council on UN Cooperation with the CSTO, SCO and CIS, 28 October. Available at: http://russiaun.ru/ru/news/sc cprsb (accessed 15 December 2017). (In Russian) 
President of Russia (2015) Russia’s National Security Strategy. Available at: http://en.kremlin.ru/events/ president/news/51129 (accessed 5 June 2018).

RIA Novosti (2016) V ODKB zajavili o rabote nad sozdaniem objedinennoj sistemy PVO i PRO [The CSTO Announced Work on the Creation of a Unified Air Defense and ABM]. RIA Novosti. Available at: https://ria.ru/defense_safety/20161207/1483060172.html (accessed 12 December 2017). (In Russian)

Shanghai Cooperation Organisation (SCO) (c. a.) Official Website. Available at: http://infoshos.ru/ $\mathrm{ru} /$ ?id=51 (accessed 5 June 2018). (In Russian)

Shanghai Cooperation Organisation (SCO) (2016) UN and SCO: Joint Counteraction to Challenges and Threats, 23 November. Available at: http://rus.sectsco.org/news/20161123/156578.html (accessed 20 December 2017). (In Russian)

Strategiya nacional'noj bezopasnosti Rossijskoj Federacii ot 2015 goda [Strategy of National Security of the Russian Federation, 2015]. Official Internet-portal of Law Information. Available at: http://pravo. gov.ru/proxy/ips/?docbody=\&nd=102385609 (accessed 5 June 2018). (In Russian)

United Nations (UN) (2010) Cooperation Between the United Nations and the Collective Security Organization. UN General Assembly Resolution A/RES/65/122. Available at: http://www.un.org/en/ga/ search/view_doc.asp?symbol=A/RES/65/122 (accessed 22 December 2017).

United Nations Bibliographic Information System (UNBISNET) (c. a.) Available at: http://unbisnet. un.org:8080/ipac20/ipac.jsp?session=150971075OW7D.41888\&profile=bib\&lang=eng\&logout=true\&s tartover=true (accessed 4 December 2017).

Voskresenskij A.D. (2012) Koncepcii regionalizacii, regional'nyh podsistem, regional'nyh kompleksov i regional'nyh transformacij v sovremennyh mezhdunarodnyh otnoshenijah [Concepts of Regionalization, Regional Subsystems, Regional Complexes and Regional Transformations in Modern International Relations]. Sravnitel'naja politika, no 2 (8), pp. 30-58. (In Russian)

Walt S.M. (1987) The Origin of Alliances. Ithaca/New York. 


\title{
Взаимосвязь глобальной и региональной систем безопасности (на примере ООН, ОДКБ и ШОС) ${ }^{1}$
}

\author{
С.А. Бокерия
}

Бокерия Светлана Александровна - к.ю.н, доцент кафедры теории и истории международных отношений Российского университета дружбы народов (РУДН); Российская Федерация, 117198, Москва, ул. МиклухоМаклая, д. 10; E-mail: bokeria_sa@pfur.ru

Статья посвящена исследованию взаимосвязи глобальной и региональной систем безопасности на примере ООН, ОДКБ и ШОС, выбор которых неслучаен. По мнению автора, их деятельность недооценена. Эти организации появились на волне возникновения пула региональных объединений стран, которые стали заниматься безопасностью и миротворческой деятельностью. Оба объединения имеют схожий состав государств-участников, созданы после распада СССР, являются наблюдателями в ООН и занимаются безопасностью как одним из ключевых направлений деятельности, имея схожие функции. ОДКБ и ШОС на постсоветском пространстве не дали вспыхнуть новым конфликтам, то есть играют роль стабилизаторов обстановки в границах своего региона и государств-участников.

Актуальность данного исследования обусловлена тремя аспектами: во-первых, особой ролью региональных организаций в выстраивании и функционировании всемирной универсальной системы безопасности; во-вторых, отсутствием исследований в отечественной науке, ориентированных на взаимодействие ООН с ОДКБ и ШОС, что, безусловно, подчеркивает научную новизну и актуальность данной работы; в-третьих, необходимостью совершенствования коллективных механизмов реагирования на существующие вызовы и новые угрозы безопасности, которые становятся взаимозависимыми.

Аналитической основой исследования стала теория военно-политических альянсов. В качестве методов исследования применяются количественный и качественный анализ документов ООН. Взаимосвязь ООН, ШОС и ОДКБ анализируется посредством методики подсчета количества и определения контекста упоминаний ключевых слов «ОДКБ» И «ШОС» в документах ООН в течение 15 (с 2002 по 2017 г.) и 16 лет (с 2001 nо 2017 г.) соответственно. Используется обширная база документов ОOH, размещенных на ресурсе UNBISNET. Ha основе полученных результатов оцениваются вклад и заинтересованность Российской Федерации как ведущего игрока на международной арене в усилении взаимосвязи глобальной и региональной систем безопасности.

Ключевые слова: ООН; региональные организации; регионализация; ОДКБ; ШОС; безопасность; миротворчество; военно-политический альянс

Для цитирования: Бокерия С.А. (2019) Взаимосвязь глобальной и региональной систем безопасности (на примере ООН, ОДКБ и ШОС) // Вестник международных организаций. Т. 14. № 1. C. 21-38. DOI: 10.17323/1996-7845-2019-01-02

\section{Источники}

Ахметов Е.Б. (2012) Успехи ШОС и обеспечение региональной военно-политической безопасности: междисциплинарный подход // Вестник КазНУ. № 4 (60). С. 11-16.

Акулик А.К., Бобков В.А., Левяш И.Я. (2011) Беларусь в интеграционных проектах. Минск: Белорусская наука.

Воскресенский А.Д. (2012) Концепции регионализации, региональных подсистем, региональных комплексов и региональных трансформаций в современных международных отношениях // Сравнительная политика. № 2 (8). С. 30-58.

\footnotetext{
${ }^{1}$ Статья поступила в редакцию в январе 2018 г.
} 
Гуанчэн С. (2002) Шанхайская организация сотрудничества в борьбе с терроризмом, экстремизмом и сепаратизмом // Центральная Азия и Кавказ. № 4. С. 13-21.

Клевакина Е.В. (2013) Организация Договора о коллективной безопасности в контексте национальных интересов стран-участниц // Вестник международных организаций. Т. 2. № 8. С. 111-129.

Колдунова Е., Дас Кунду Н. (2014) Роль России в ШОС и Центральной Азии: вызовы и возможности. Режим доступа: http://vid-1.rian.ru/ig/valdai/SCO_rus.pdf (дата обращения: 20.12.2017).

Лузянин С.Г. (2013) Шанхайская организация сотрудничества 2013-2015. Прогнозы, сценарии и возможности развития. М.: ИДВ РАН.

Лукин А.В. (2011) Шанхайская организация сотрудничества и российские интересы в Центральной Азии и Афганистане // Вестник МГИМО Университета. № 5. С. 37-47.

Министерство иностранных дел Российской Федерации (2016) Концепция внешней политики РФ от 2016 г. Режим доступа: http://www.mid.ru/foreign_policy/news/-/asset_publisher/cKNonkJE02Bw/content/id/2542248 (дата обращения: 13.12.2017).

Назарбаев Н.А. (2011) Евразийский союз: от идеи к истории будущего // Известия. Режим доступа: http://izvestia.ru/news/504908 (дата обращения: 21.12.2017).

Организация Договора о коллективной безопасности (ОДКБ) (2002) Устав ОДКБ. Режим доступа: http://www.odkb-csto.org/documents/detail.php?ELEMENT_ID=124 (дата обращения: 11.12.2017).

Организация Договора о коллективной безопасности (ОДКБ) (2012) Договору о коллективной безопасности 20 лет. Режим доступа: http://www.odkb-csto.org/media/buklet.pdf (дата обращения: 11.12.2017)

Организация Договора о коллективной безопасности (ОДКБ) (б. г.) Официальный сайт. Режим доступа: http://www.odkb-csto.org/documents/detail.php?ELEMENT_ID=1672 (дата обращения: 05.06.2018).

Постоянное представительство РФ при ООН (2016) Выступление Постоянного представителя РФ при ООН В.И. Чуркина на заседании СБ ООН в 2016 г., посвященном сотрудничеству ООН с ОДКБ, СНГ и ШОС. Режим доступа: http://russiaun.ru/ru/news/sc_cprsb (дата обращения: 15.12.2017).

Президент России (2015) О Стратегии национальной безопасности Российской Федерации. Режим доступа: http://kremlin.ru/acts/bank/40391 (дата обращения: 05.06.2018).

РИА Новости (2016) В ОДКБ заявили о работе над созданием объединенной системы ПВО и ПРО. Режим доступа: https://ria.ru/defense_safety/20161207/1483060172.html (дата обращения: 12.12.2017).

Хачатуров Ю. (2017) ОДКБ - 15 лет вместе во имя безопасного мира и стабильного развития. ТАСС. Режим доступа: http://tass.ru/opinions/4276931 (дата обращения: 15.12.2017).

Шанхайская организация сотрудничества (ШОС) (2016) ООН и ШОС: совместное противодействие вызовам и угрозам. Режим доступа: http://rus.sectsco.org/news/20161123/156578.html (дата обращения: 20.12.2017).

Шанхайская организация сотрудничества (ШОС) (б. г.) Центральный интернет-портал ШОС. Режим доступа: http://infoshos.ru/ru/?id=51 (дата обращения: 11.12.2017).

Bailes A., Dunay P., Guang P., Troitsky M. (2007) Shanghai Cooperation Organization. Stockholm: SIPRI.

Holsti O., Hopmann T., Sullivan J. (1973) Unity and Disintegration in International Alliances: Comparative Studies. N. Y.: John Wiley \& Sons.

Liska G. (1968) Nations in Alliance: The Limits of Interdependence. Baltimore: Johns Hopkins Press.

United Nations (UN) (2010) Cooperation Between the United Nations and the Collective Security Organization. UN General Assembly Resolution A/RES/65/122. Режим доступа: http://www.un.org/en/ga/search/ view_doc.asp?symbol=A/RES/65/122 (дата обращения: 22.12.2017).

United Nations Bibliographic Information System (UNBISNET) (с. а.) Режим доступа: http://unbisnet. un.org:8080/ipac20/ipac.jsp?session=150971075OW7D.41888\&profile=bib\&lang=eng\&logout $=$ true\&startov er=true (дата обращения: 04.12.2017).

Walt S.M. (1987) The Origin of Alliances. Ithaca/New York. 